\title{
Mechanism and control strategy of ammonia and nitrous oxide during composting of municipal solid wastes
}

\author{
CHEN Yi-xiao ${ }^{1, a}$, LU Yi-ming ${ }^{1}$, MO Jin-tao ${ }^{1}$, PAN Jia-jing ${ }^{1}$ and ZHANG Jun ${ }^{1, b^{*}}$ \\ ${ }^{1}$ College of Environmental Science and Engineering, Guilin University of Technology, 541006 Guilin, China
}

\begin{abstract}
Aerobic composting is an effective way to realize recycling of organic solid wastes. It is not only convenient for operation and management, but also can convert waste into organic fertilizer. However during the composting process, the nitrogen in the heap exists in the form of organic nitrogen, ammonium nitrogen, nitrate nitrogen and other forms and is transformed into each other. It is also a potential source of ammonia $\left(\mathrm{NH}_{3}\right)$ and nitrous oxide $\left(\mathrm{N}_{2} \mathrm{O}\right)$, and it is closely related to the environmental problems such as haze pollution and greenhouse effect. Combining with the researches of domestic and foreign scholars, this paper summarizes the form transformation of nitrogen elements, the emission mechanism of $\mathrm{NH}_{3}$ and $\mathrm{N}_{2} \mathrm{O}$, and the adjustment and control measures in the aerobic composting process of the organic solid wastes, and it prospects the research direction for aerobic composting of the organic solid wastes.
\end{abstract}

\section{Introduction}

In recent years, most of the organic solid wastes are randomly discarded or discharged into the environment, causing great negative impacts on the ecological environment. Municipal sludge is waste generated in the process of sewage treatment. If the sludge that has not been properly treated enters the environment directly, it will cause secondary pollution to the environment. Kitchen waste is easy to decay and deteriorate, and it is easy to breed bacteria. If placed improperly, it will have adverse effects on the social environment and human health. Aerobic composting is an effective way for minimization, hazard-free treatment and resourceful disposal of the organic solid wastes such as municipal sludge, kitchen wastes and livestock excrements. In the conditions of good ventilation and appropriate oxygen concentration, aerobic microorganisms multiply rapidly to degrade the organic solid wastes into organic fertilizers rich in humus and nutrient elements such as N, P, K [1-2].

However, the composting process is accompanied by $\mathrm{NH}_{3}$ and $\mathrm{N}_{2} \mathrm{O}$ emissions. $\mathrm{NH}_{3}$ is an important precursor gas for the formation of $\mathrm{PM}_{2.5}$, and it is easily soluble in water. When the relative humidity is high, it can react with $\mathrm{H}_{2} \mathrm{SO}_{4}, \mathrm{HNO}_{3}$ and $\mathrm{HCl}$ in the atmosphere to generate the secondary particles of ammonium salt, which is an important part of $\mathrm{PM}_{2.5}$ it can cause haze pollution to reduce the quality of the atmospheric environment, but also it threatens the human health [3]. $\mathrm{N}_{2} \mathrm{O}$ is an important greenhouse gas that affects the radiation balance of the earth. Within 100 years, its single-molecule warming potential is 296 times of $\mathrm{CO}_{2}$, which has a significant impact on the global greenhouse effect [4-5]. In summary, if the composting process is not properly controlled, the emitted $\mathrm{NH}_{3}$ and $\mathrm{N}_{2} \mathrm{O}$ will not only affect the global

${ }^{*}$ Corresponding author: ${ }^{\mathrm{b}} \mathrm{zj} u n @$ glut.edu.cn

a1020200338@glut.edu.cn climate change, but also cause harm to various organisms, including the human health. Therefore, the research on reducing $\mathrm{NH}_{3}$ and $\mathrm{N}_{2} \mathrm{O}$ emissions during composting attracts more and more attention from scholars at home and abroad.

\section{The form transformation of nitrogen elements during composting}

The composting process is divided into the heating-up period, the high temperature period and the cooling and maturing period. Among them, the nitrogen elements mainly exist in the form of organic nitrogen, ammonium nitrogen and nitrate nitrogen [6], and they are transformed by mediating of microbial communities through ammonification, nitrification, denitrification and ammonia assimilation (Fig. 1).

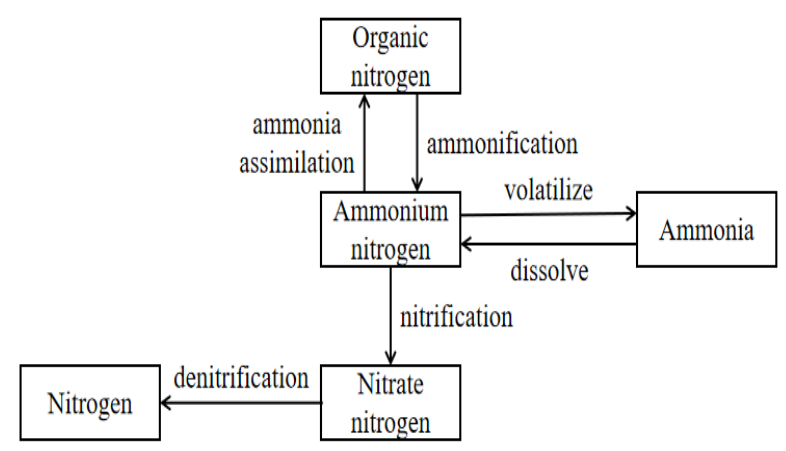

Fig.1 Transformation paths of nitrogen element in composting

Ammonification is a process in which organic nitrogen is decomposed by microorganisms to form $\mathrm{NH}_{4}{ }^{+}$. It is divided into two periods: First, the organic nitrogen in the 
waste pile is decomposed into amino compounds under the catalysis of proteases. And then, the amino compounds are transformed to be $\mathrm{NH}_{4}{ }^{+}$in the deamination process. The ammoniating reaction may occur throughout the composting cycle, and it is more intense in the heating stage, because the initial pile contains a large amount of organic nitrogen, and the temperature and $\mathrm{pH}$ are suitable at this time. The increase in temperature and $\mathrm{pH}$ will cause a large amount of $\mathrm{NH}_{4}{ }^{+}$to volatilize in the form of $\mathrm{NH}_{3}$. In addition, $\mathrm{NH}_{4}^{+}$can be oxidized to $\mathrm{NO}_{3}^{-}$through nitrification, or it can be utilized by microorganisms to synthesize organic nitrogen as nutrients of ammonia assimilation [7-8].

Nitrification is a process in which $\mathrm{NH}_{4}{ }^{+}$is successively oxidized to $\mathrm{NO}_{3}^{-}$by nitrifying bacteria. Ammonia oxidation is the first step of nitrification, which is divided into two periods: One is that $\mathrm{NH}_{3}$ is oxidized to $\mathrm{NH}_{2} \mathrm{OH}$ under the action of ammonia monooxygenase; the other is that $\mathrm{NH}_{2} \mathrm{OH}$ is oxidized to $\mathrm{NO}_{2}^{-}$under the action of hydroxylamine oxidoreductase; and as an intermediate product of ammoxidation, $\mathrm{NH}_{2} \mathrm{OH}$ can further react with $\mathrm{NO}_{2}{ }^{-}$to form $\mathrm{N}_{2} \mathrm{O}$. The $\mathrm{NO}_{3}{ }^{-}$generated by nitrification can be absorbed and utilized by plants to synthesize nitrogencontaining organic matters, or it can be transformed to $\mathrm{N}_{2}$ through denitrification in anaerobic conditions [9-10].

Denitrification is the process in which $\mathrm{NO}_{3}{ }^{-}, \mathrm{NO}_{2}{ }^{-}, \mathrm{NO}$ and $\mathrm{N}_{2} \mathrm{O}$ are successively reduced to $\mathrm{N}_{2}$ by denitrifying bacteria. The accumulation or compaction of the compost materials will prevent oxygen from entering the inside of the waste pile to form a local anaerobic environment and promote denitrification. Pseudomonas and paracoccus are typical aerobic denitrifying microorganisms, and their abundance is relatively less during the heating-up period of composting, and it will be gradually increased until the high temperature period and the cooling and maturing period [11-12].

Ammonia assimilation is a process in which $\alpha$ ketoglutarate, an intermediate product of $\mathrm{NH}_{4}{ }^{+}$and carbon source metabolism, is catalyzed to synthesize glutamate and finally transformed to organic nitrogen. The synthesis of glutamate by $\mathrm{NH}_{4}{ }^{+}$can be achieved in two ways, one is that glutamate dehydrogenase catalyzes $\mathrm{NH}_{4}{ }^{+}$to directly reacts with $\alpha$-ketoglutarate; the other is that glutamine synthetase acts together with glutamate synthetase, and it catalyzes $\mathrm{NH}_{4}^{+}$to react with $\alpha$-ketoglutarate and glutamine [13-14].

\section{The emission mechanism of $\mathrm{NH}_{3}$ and $\mathrm{N}_{2} \mathrm{O}$ during composting}

The organic nitrogen in the waste pile undergoes ammoniating to form $\mathrm{NH}_{4}{ }^{+}$. As the temperature and the $\mathrm{pH}$ increase, $\mathrm{NH}_{4}{ }^{+}$is quickly transformed to $\mathrm{NH}_{3}$, which accelerates the emission of $\mathrm{NH}_{3}$. Therefore, the high temperature period is the main period of $\mathrm{NH}_{3}$ volatilization during the composting process. When the temperature of the waste pile is reduced to the air temperature, the composting enters the maturing period. At this time, the content of $\mathrm{NH}_{4}^{+}$decreases and the volatilization rate of $\mathrm{NH}_{3}$ also decreases due to the nitrification and the ammonia assimilation of $\mathrm{NH}_{4}{ }^{+}$as well as the continuous volatilization of $\mathrm{NH}_{3}$ [15-16].

In the composting process, both the nitrification of $\mathrm{NH}_{4}{ }^{+}$and the denitrification of $\mathrm{NO}_{3}{ }^{-}$will cause emission of $\mathrm{N}_{2} \mathrm{O}$. Maeda et al. [17] use the priority point value (SP) to study the $\mathrm{N}_{2} \mathrm{O}$ emission mechanism of the cattle manure composting process. The results show that the SP value of $\mathrm{N}_{2} \mathrm{O}$ emission in the initial stage of composting is 0 to 12 , and the $\mathrm{N}_{2} \mathrm{O}$ emission reaches the peak after the turning over the pile, the corresponding SP value is 0 to 5 , while the $\mathrm{SP}$ value of $\mathrm{N}_{2} \mathrm{O}$ emitted by nitrification is about 33 , and the $\mathrm{SP}$ value of $\mathrm{N}_{2} \mathrm{O}$ emitted by denitrification is about 0 , which indicates that $\mathrm{N}_{2} \mathrm{O}$ can come from both nitrification and denitrification, and denitrification is the main way to produce $\mathrm{N}_{2} \mathrm{O}$ during the composting process. The researches of $\mathrm{Ge}$ et al. [11] show that, during the compost heating-up period and the high temperature period, $\mathrm{N}_{2} \mathrm{O}$ is mainly emitted through the nitrification process led by ammonia oxidizing bacteria; when entering the cooling and maturing period, $\mathrm{N}_{2} \mathrm{O}$ is mainly emitted through the denitrification process of ammonia oxidizing bacteria and denitrifying bacteria.

\section{The reduction measures of $\mathrm{NH}_{3}$ and $\mathrm{N}_{2} \mathrm{O}$ during composting}

The initial characteristics of compost material such as temperature, $\mathrm{pH}$, and moisture content significantly affect the carbon and nitrogen metabolism, and then affect the production and emission of $\mathrm{NH}_{3}$ and $\mathrm{N}_{2} \mathrm{O}$ during the composting process. The biochemical reactions in aerobic composting are generally manifested by temperature changes. $\mathrm{pH}$ is not only related to the life activities of microorganisms, but also closely related to the existence of ammonium nitrogen [18]. The moisture content of the compost material is generally $50 \%$ to $70 \%$, which mainly affects the diffusion of $\mathrm{O}_{2}$ in the waste pile, thereby indirectly affects the emission of $\mathrm{NH}_{3}$ and $\mathrm{N}_{2} \mathrm{O}$ during the composting process [19]. Too high water content is not conducive to the diffusion of $\mathrm{O}_{2}$ in the waste pile, which weakens the mineralization of organic nitrogen thus reducing the emission of $\mathrm{NH}_{3}$ [20]. When the moisture content of the material reaches more than $60 \%, \mathrm{~N}_{2}$ is formed mainly by denitrification of nitrogen elements, so that the emission of $\mathrm{N}_{2} \mathrm{O}$ is reduced [21]. Therefore, it is possible to reduce the emission of $\mathrm{NH}_{3}$ and $\mathrm{N}_{2} \mathrm{O}$ during the composting process by adjusting and controlling the moisture content of material. For raw materials with low moisture content, it can be adjusted by adding water. When the raw material has a high moisture content, auxiliary materials such as straw and sawdust can be added.

Ventilation conditions have an important impact on the emissions of $\mathrm{NH}_{3}$ and $\mathrm{N}_{2} \mathrm{O}$ during composting. Turning the pile will increase the $\mathrm{O}_{2}$ concentration in the pile, thereby promoting the mineralization of organic nitrogen and increasing the volatilization of $\mathrm{NH}_{3}$ [22]. It is generally believed that the amount of ammonia volatilization is positively correlated with the frequency of dumping [23]. Turn over the pile to homogenize the material, and the $\mathrm{NO}_{\mathrm{x}}{ }^{-}$inside the pile body undergoes denitrification to generate $\mathrm{N}_{2} \mathrm{O}$, thereby increasing $\mathrm{N}_{2} \mathrm{O}$ 
emissions[24]. Zhao et al. [25] investigate the effect of turning frequency on greenhouse gas and ammonia emissions during the composting process of pig manure strips, and the results show that the increasing of turnover frequency has increased greenhouse gas and ammonia emissions. The intermittent ventilation method has a good emission reduction effect on $\mathrm{NH}_{3}$ and $\mathrm{N}_{2} \mathrm{O}$ generated during the composting process. Zhang et al. [26] adopt three intermittent ventilation methods to carry out the composting experiment, and the results show that, the emission of $\mathrm{NH}_{3}$ is the least after a 20-minute stop for every 40 minutes of ventilation. Ma et al. [27] find that, the intermittent ventilation method of a 10-minute stop for every 10 minutes of ventilation can reduce the emission of $\mathrm{N}_{2} \mathrm{O}$ by $47.10 \%$.

Adding conditioners is an effective strategy to reduce $\mathrm{NH}_{3}$ and $\mathrm{N}_{2} \mathrm{O}$ emissions during composting. Physical additives have abundant pore structures and negative charge adsorption sites, which can adsorb $\mathrm{NH}_{3}$ and $\mathrm{NH}_{4}{ }^{+}$, and it can reduce the abundance of genes related to $\mathrm{N}_{2} \mathrm{O}$ production and increase the abundance of genes related to $\mathrm{N}_{2} \mathrm{O}$ reduction, so that $\mathrm{N}_{2} \mathrm{O}$ emissions such as biochar, medical stone, bentonite, etc. are reduced [18]. Biochar reduces $\mathrm{NH}_{3}$ emissions by $28.30 \sim 74.32 \%$ and $\mathrm{N}_{2} \mathrm{O}$ emissions by $79.51 \sim 81.10 \%$ [28]; while medical stone reduces $\mathrm{NH}_{3}$ emissions by $38.20 \sim 78.50 \%$ and $\mathrm{N}_{2} \mathrm{O}$ emissions by $46.60 \sim 82.40 \%$ [29]. Chemical additives can reduce $\mathrm{NH}_{3}$ emissions by lowering the $\mathrm{pH}$ of the material, fixing $\mathrm{NH}_{4}{ }^{+}$or reacting with $\mathrm{NH}_{4}^{+}$[30]. When Lei et al. [31] add phosphogypsum, the $\mathrm{NH}_{3}$ emissions are reduced by $59.74 \%$, while the $\mathrm{N}_{2} \mathrm{O}$ emissions are increased by $8.15 \%$. This may be the reason that the chemical additives reduce the $\mathrm{pH}$ of the material and inhibit activity of the $\mathrm{N}_{2} \mathrm{O}$ reductase. In addition, the promotion of nitrification or assimilation of $\mathrm{NH}_{4}{ }^{+}$through biological additives can reduce the $\mathrm{NH}_{3}$ emissions by $10.20 \%$ to $42.80 \%$ [30]. Jiang et al. [32] find that, when the addition amount of dicyandiamide was higher than $2.5 \%$, the nitrification is inhibited, and the $\mathrm{N}_{2} \mathrm{O}$ emissions is reduced by $77 \%$.

\section{Conclusions}

The reduction measures of $\mathrm{NH}_{3}$ and $\mathrm{N}_{2} \mathrm{O}$ emission during the composting process include the conditioning of material properties, the optimization of process conditions, the addition of conditioners, etc. At present, the emission reduction mechanism of $\mathrm{NH}_{3}$ and $\mathrm{N}_{2} \mathrm{O}$ in the composting process still needs to be explored. This is because the adjustment and control measures will affect multiple factors at the same time, and the trade-off phenomenon may even occur. Therefore, in the future, it is necessary to increase research on the influencing factors of composting effect, and further narrow the scope of the most suitable conditions for operation. In addition, on the basis of adjusting the material properties and optimizing the process conditions, the use of additives shall be combined to realize the coordinated emission reduction of $\mathrm{NH}_{3}$ and $\mathrm{N}_{2} \mathrm{O}$ during the composting process. Aerobic composting can not only reduce environmental pressure, but also make organic solid waste resources. With the continuous deepening of research, the improvement of composting technology will make aerobic composting more environmentally friendly, more efficient, and more suitable for large-scale composting.

\section{References}

1. Bai, M., Impraim, R., Coates, T.W., et al. (2020) Lignite effects on $\mathrm{NH}_{3}, \mathrm{~N}_{2} \mathrm{O}, \mathrm{CO}_{2}$ and $\mathrm{CH}_{4}$ emissions during composting of manure. Journal of Environmental Management, 271:110960.

2. He, X., Yin, H., Fang, C., et al. (2021) Metagenomic and q-PCR analysis reveals the effect of powder bamboo biochar on nitrous oxide and ammonia emissions during aerobic composting. Bioresource Technology, 323:124567.

3. Jiang, B.F., Xia, D.H. (2017) Role identification of $\mathrm{NH}_{3}$ in atmospheric secondary new particle formation in haze occurrence of China. Atmospheric Environment, 163:107-117.

4. Ma, S., Xiong, J., Cui, R., et al. (2020) Effects of intermittent aeration on greenhouse gas emissions and bacterial community succession during large-scale membrane-covered aerobic composting. Journal of Cleaner Production, 266:121551.

5. Wu, W.X., Li, L.J., Lv, H.H., Wang, C., Deng, H. (2012) Mechanisms of nitrous oxide emission during livestock manure aerobic composting. Chinese Journal of Applied Ecology, 23(06):1704-1712.

6. Shi, M.Z., Zhao, Y., Zhu L.J., Song, X.Y., Tang, Y., Qi, H.S., Cao, H.G., Wei, Z.M. (2020) Denitrification during composting: Biochemistry, implication and perspective. International Biodeterioration \& Biodegradation, 153:105043.

7. Huang, Y., Li, D.Y., Wang, L., et al. (2019) Decreased enzyme activities, ammonification rate and ammonifiers contribute to higher nitrogen retention in hyperthermophilic pretreatment composting. Bioresource Technology, 272:521-528.

8. Ma, C., Hu, B., Liu, F.Y., Zhang, H.Z., Wei, M.B., Zhao J.H. (2019) Review on changes of microorganisms and enzyme activities during aerobic composting of organic waste. Environmental Engineering, 37(09): 159-164+187.

9. Caceres, R., Malinska, K., Marfa, O. (2018) Nitrification within composting: A review. Waste Management, 72:119-137.

10. Maeda, K., Dai, H., Toyoda, S., et al. (2011) Microbiology of nitrogen cycle in animal manure compost. Microbial Biotechnology, 4(6):700-709.

11. Ge, J.Y., Huang, G.Q., Li, J.B., et al. (2018) Multivariate and multiscale approaches for interpreting the mechanisms of nitrous oxide emission during pig manure-wheat straw aerobic composting. Environmental Science \& Technology, 52(15):8408-8418.

12. Fukumoto,Y., Suzuki,K., Kuroda, K., et al. (2011) Effects of struvite formation and nitratation promotion on nitrogenous emissions such as $\mathrm{NH}_{3}$, 
$\mathrm{N}_{2} \mathrm{O}$ and $\mathrm{NO}$ during swine manure composting. Bioresource Technology, 102(2):1468-1474.

13. Wang, S.J., Zeng, Y. (2018) Ammonia emission mitigation in food waste composting: A review. Bioresource Technology, 248:13-19.

14. Shou, Z.Q., Zhu,N.W., Yuan, H.P., Dai, X.H., Shen, Y.W. (2019) Buffering phosphate mitigates ammonia emission in sewage sludge composting: Enhanced organics removal coupled with microbial ammonium assimilation. Journal of Cleaner Production, 227:189198.

15. Guo, H.H., Gua, J., Wang, X.J., et al. (2020) Microbial driven reduction of $\mathrm{N}_{2} \mathrm{O}$ and $\mathrm{NH}_{3}$ emissions during composting: Effects of bamboo charcoal and bamboo vinegar. Journal of Hazardous Materials, 390:121292.

16. Meng, L.Q., Li, W.J., Zhang, S.M, et al. (2016) Effect of different extra carbon sources on nitrogen loss control and the change of bacterial populations in sewage sludge composting. Ecological Engineering, 94:238-243.

17. Maeda, K., Toyoda, S., Philippot, L., et al. (2017) Relative contribution of nirK- and nirS- bacterial denitrifiers as well as fungal denitrifiers to nitrous oxide production from dairy manure compost. Environmental Science \& Technology, 51:1408314091.

18. Liao, L.M., Zhao, L.J., Lu, Y.X., Chen, M.L., Su, C.Y. (2019) Nitrogen transformation and loss control strategy during composting of municipal solid wastes. Environmental Engineering, 37(02):133-137.

19. Cao, Y.B., Zhang, L., Wang, X., et al. (2020) Synergistic mitigation of ammonia and greenhouse gas emissions during livestock waste composting. Journal of Agro-Environment Science, 39(4): 923932.

20. Fan, H., Liao, J., Abass, O.K., et al. (2019) Effects of bulking material types on water consumption and pollutant degradation in composting process with controlled addition of different liquid manures. Bioresource Technology, 288:121517.

21. Chen, H., Wang J.Y., Tian, X.F., et al. (2019) Effects of different water content and $\mathrm{C} / \mathrm{N}$ coupling on greenhouse gas emissions during donkey dung composting. Ecology and Environmental Sciences, 28(2):341-347.

22. Pardo, G., Moral, R., Aguilera, E., et al. (2015) Gaseous emissions from management of solid waste: A systematic review. Global Change Biology, 21(3):1313-1327.

23. Cao, Y.B., Xing, X.X., Bai, Z.H., et al. (2018) Review on ammonia emission mitigation techniques of crop livestock production system. Scientia Agricultura Sinica, 51(3):566-580.

24. Jiang, T., Frank, S., Li, G.X. (2011) Effect of turning and covering on greenhouse gas and ammonia emissions during the winter composting. Transactions of the CSAE, 27(10):212-217.
25. Zhao, C.Y., Li, H.M., Wei, Y.S., et al. (2014) Effects of turning frequency on emission of greenhouse gas and ammonia during swine manure windrow composting. Environmental Science, 35(2):533-540.

26. Zhang, H., Wang, G.Q., Gu, J., et al. (2017) Influence of ventilation on $\mathrm{H}_{2} \mathrm{~S}$ and $\mathrm{NH}_{3}$ emission during kitchen waste composting. Journal of China Agricultural University, 22(12):124-130.

27. Ma, S., Xiong, J., Cui, R., et al. (2020) Effects of intermittent aeration on greenhouse gas emissions and bacterial community succession during large-scale membrane-covered aerobic composting. Journal of Cleaner Production, 266:121551.

28. Wang, C., Lu, H., Dong, D., et al. (2013) Insight into the effects of biochar on manure composting: Evidence supporting the relationship between $\mathrm{N}_{2} \mathrm{O}$ emission and denitrifying community. Environmental Science \&Technology, 47(13):7341-7349.

29. Awasthi, M.K., Wang, Q., Awasthi, S.K., Wang, M., Chen, H., Ren, X., Zhao, J., Zhang, Z, (2018) Influence of medical stone amendment on gaseous emissions, microbial biomass and abundance of ammonia oxidizing bacteria genes during biosolidscomposting. Bioresource Technology, 247:970-979.

30. Cao, Y., Wang, X., Bai, Z., et al. (2019) Mitigation of ammonia, nitrous oxide and methane emissions during solid waste composting with different additives: A meta-analysis. Journal of Cleaner Production, 235:626-635.

31. Lei, L., Gu, J., Wang, X., et al. (2020) Effects of phosphogypsum and medical stone on nitrogen transformation, nitrogen functional genes, and bacterial community during aerobic composting. Science of The Total Environment, 753(9-10):141746.

32. Jiang, T., Ma, X., Tang, Q., et al. (2016) Combined use of nitrification inhibitor and struvite crystallization to reduce the $\mathrm{NH}_{3}$ and $\mathrm{N}_{2} \mathrm{O}$ emissions during composting. Bioresource Technology, 217:210-218. 